\title{
Studies on BB Resistance Introgression in Aromatic Rice Variety Keteki Joha
}

\author{
Gongotri Hazarika*, Sanjay Kumar Chetia, Sunayana Bordoloi, \\ Amrit Tamuly and T. Ahmed
}
Regional Agricultural Research Station, Assam Agricultural University, Titabar 785 630, Assam, India

*Corresponding author

\section{Keywords \\ Bacterial leaf blight, Xanthomonas oryzae (Zoo), Microsatellite markers, Resistance gene \\ Article Info \\ Accepted: \\ 04 August 2019 \\ Available Online: \\ 10 September 2019}

\section{A B S T R A C T}

Keteki joha, one of the most popular aromatic rice variety of our region was found to be resistant towards $\mathrm{BB}$ earlier, but is also becoming highly infested by the disease now a days. This may be due to the climatic change which may lead to the evolution of new races of the pathotype which might not exist earlier in Assam. Bacterial blight (BB) caused by Xanthomonas oryzae $p v$. oryzae (Xoo) is one of the most devastating diseases affecting entire rice acreages. It causes severe yield losses of up to $80 \%$ depending on the stage of the crop, cultivar susceptibility, and environmental conditions. An effectual and well founded chemical control method of the disease is not available. To save the crop from this deleterious disease, intensification of host plant resistance is the viable option, but it is hard to attain the required resistance through conventional breeding. Therefore the introgression of resistance genes of BB is the greatest possible way to tackle this disease and raise the productivity of the rice cultivation. The resistant varieties carrying resistance genes have been utilized to control the disease. A number of rice genes have been identified along with its closely linked microsatellite markers that confer resistance against $X$. Oryzae pv. oryzae. Out of these resistant genes $-X a 4$, $x a 5, x a 13$ and $X a 21$ have been introgressed in different combinations in the background of popular rice varieties of our country and exhibiting resistance by the introgressed varieties. Identification of parental polymorphism between the recipient and the donor variety is of prime importance to introgress the resistant gene. For introgression of Xa4, xa5, xa13 and Xa21, polymorphic molecular markers has been identified between the donor Improved Sambha Mahsuri and recipient Keteki joha; RM144 for Xa4, RM122 for xa5, xa13 for xa13 and pTa248 for $\mathrm{Xa21}$. It was found that in Assam the prevalent pathotypes of $X$. oryzae pv. oryzae were III, $\mathrm{V}$, VIII and IX. However, even after the presence of $x a 5$ resistant gene which confers resistance against pathotypes V and VIII, Keteki Joha was found to be susceptible to BB infection, this may be due to evolution of new races III and IX. xa5 gene alone cannot confer complete resistance against the prevalent pathotype of Assam. Therefore, for complete resistance against the prevalent BB pathotype, a combination of other BB resistance genes-xa13 and Xa21 along with $x a 5$ has to be introgressed. 


\section{Introduction}

Rice (Oryzae sativa L) is the most widely consumed staple food crop for nearly half of the world's population. Unfortunately, its production is restricted by a considerable number of diseases of fungal, bacterial, and viral origin. Bacterial Leaf Blight (BB) caused by the Gram-negative bacteria Xanthomonas oryzae (Xoo) is one of the most highly destructive diseases of rice cultivation worldwide. It causes Linear yellow to straw color stripes with wavy margins, generally on both edges of the leaf, rarely on one edge. Stripes usually start from tips and extend downwards, drying and twisting of the leaf tip. Symptoms may appear 4-5 days after transplanting. The disease being systemic, effective chemical control measures are lacking (Devadath, 1989) and the concern over health hazards of pesticides limited the utilization of chemical control agents (Guillebeau, 1998). Breeding for disease resistance is the most important approach for its management (Sanchez et al., 2000; Singh et al., 2001, Zhang 2005; Nino-Lui et al., 2006; Sundaram et al., 2008; Mamgain et al., 2013). Conventional breeding methods are inefficient for gene determination, particularly in case of recessively inherited resistance genes. These limitations can be overcome by the marker assisted selection (MAS), which enables the evaluation of the expression of resistance gene and allows for pyramiding of multiple resistance genes in susceptible varieties. (khan et al., 2015 ).

To date, atleast $41 \mathrm{BB}$ resistance genes conferring host resistance against various strains of Xoo has been identified (Hutin et al., 2015). All these resistance genes follow a Mendelian pattern of major gene inheritance and express resistance to a diverse group of Xoo pathogens (Cheema, 2008; Gu. 2005; Korinsak 2009; Lee 2003; Sun 2004). Of the $41 \mathrm{R}$ genes, six are physically mapped(Xa2,
$X a 4, X a 7, X a 30, X a 33$ and Xa38) and six are cloned (Xa1, xa5, Xa13, Xa21, Xa26, Xa3 and $\mathrm{Xa27}$ ) (Bhasin. 2012; Cheema, 2008; Gu, 2005; Liu, 2006; Natrajkumar, 2012; Yang, 1998). Several BB resistance gene has been associated with tightly linked DNA markers and some of them have been cloned (Xa1, xa5, $X a 13, X a 21, X a 26, X a 27)$ and used for breeding BB-resistant rice cultivars (Ali Sattari et al., 2014). Molecular markers can be used as indirect indicators of the presence of a resistance gene. Because of the availability of DNA markers derived from the resistance genes it is possible to detect the level of polymorphism between different BB resistance gene. It has been reported during release that the popular rice variety of Assam, Keteki Joha is moderately resistant to BB. However, the gene conferring its resistance to $\mathrm{BB}$ has not been identified yet.

The main objective of this study is PCR polymorphism survey of different $X a$ genes in the two different rice varieties namely Keteki joha and Improved Samba Mahsuri (ISM) and Introgression of $\mathrm{BB}$ resistance in Keteki Joha as well.

Screening of the IRBB isogenic lines with different combinations of BB resistance genes $X a 4, x a 5, x a 13$ and $X a 21$ for field virulence showed that the the gene combinations $x a 5+x a 13, X a 4+x a 5+x a 13, X a 4+x a 5+X a 21$, $X a 4+x a 13+X a \quad 21, \quad x a 5+x a 13+X a 21$ and $X a 4+x a 5+x a \quad 13+X a 21$ confer complete resistance against the $\mathrm{BB}$ pathotypes prevalent in Assam (Chetia et al., 2016).

In Assam the prevalent pathotypes of $X$. oryzae pv oryzae are III, V, VIII, IX (Mishra et al., 2013). As reported earlier, the presence of $\mathrm{Xa4}$ gene shows susceptible reaction against pathotype III and IX and moderately resistant reaction against pathotype $\mathrm{V}$ and VIII. xa5 gene gives susceptible reaction against pathotype III, moderately resistant 
reaction against pathotype $\mathrm{V}$ and complete resistance against pathotype VIII and IX. Presence of xal3 gene gives complete resistance against pathotype III and V and susceptible reaction against pathotype VIII and IX. The Xa21 gene gives moderately resistant reaction against pathotype III and IX and complete resistance against pathotype $\mathrm{V}$ and VIII (Mishra et al., 2013)

Improved Sambha Mahsuri exhibits resistance to $\mathrm{BB}$, whereas Keteki joha is highly susceptible to $\mathrm{BB}$. The aromatic rice variety was notified during 1997 and during that period the variety was tolerant to $\mathrm{BB}$. However the variety becoming highly susceptible to $\mathrm{BB}$ may be due to evolution of new races of $\mathrm{BB}$ pathogen. ISM has three major bacterial blight resistance genes $X a 21$, $x a 13$ and $x a 5$. The resistance gene to BB Xa4, $x a 13$ and $X a 21$ links to the sequence-taggedsite(STS) markers Npb181, RG136 and pTa248 respectively; the resistance genes $x a 5$ and $x a 13$ tightly link to the simple sequence repeat marker RM122 and xa13 promoter respectively. These markers are used to confer the presence of each gene and gene combinations in the two rice varieties.

\section{Materials and Methods}

To conduct the experiment, Improved Samba Mahsuri has been considered as donor parent for introgression of Bacterial Blight (BB) resistance in Keteki Joha. The varieties, Keteki Joha and Improved Samba Mahsuri were staggered planted in an interval of 10 days at the research farm, RARS, Titabar, Assam during Kharif 2016. Leaf samples of these varieties were taken for DNA extraction and PCR analysis.

The crossing program was initiated and crosses were attempted considering Keteki Joha as female parent. The cross seed was harvested during second week of November, 2016.

\section{Identification of polymorphic markers}

\section{DNA extraction}

Total genomic DNA was isolated from the leaves of the rice Keteki Joha and Improved Samba Mahsuri using the DNA isolation protocol suggested by Zheng et al., Healthy rice leaf sample was collected and ground in $1 \mathrm{ml}$ of extraction buffer $(50 \mathrm{mM}$ TrisHCl $\mathrm{pH}$ 8.0, 25mM EDTA pH 8.0, 300mM NaCl, $1 \%$ SDS). The tissue was ground until the buffer turned dark green and transferred into a $2 \mathrm{ml}$ centrifuge tube. The tube was then kept in a water bath at $65^{\circ} \mathrm{C}$ for about an hour. The supernatant was collected after centrifugation at $10,000 \mathrm{rpm}$ for 20 minutes and equal volume of chloroform: isoamyl alcohol (24:1) was added, mixed well. After centrifugation at $10,000 \mathrm{rpm}$ for 10 minutes, the upper aqueous layer was carefully collected and double the volume of chilled absolute ethanol was added. The precipitated DNA was collected after centrifugation at $10,000 \mathrm{rpm}$ for 15 minutes and the DNA pellet was allowed to dry. $50 \mu \mathrm{l}$ of TE buffer $(10 \mathrm{mM}$ TrisHCl pH 8.0 and $1 \mathrm{mM}$ EDTA $\mathrm{pH}$ 8.0) was added to dissolve the DNA and stored at $-20^{\circ} \mathrm{C}$ for further use.

\section{PCR amplification}

The polymorphism survey was carried out for the donor (ISM) and recurrent parent (Keteki Joha) for the target genes $\mathrm{Xa} 4, x a 5, x a 13$ and $X a 21$ for their use in foreground selection in the marker assisted backcross program using the markers- Npb181, RM144 for Xa4; RM122 for $x a 5$; xa13 promoter, RG136 for xa13 and pTa248-STS for Xa21, respectively.

The PCR mixture contained 50ng of template DNA, 5 picomoles of each primer, $0.05 \mathrm{mM}$ dNTPs, 1X PCR buffer and 1U Taq DNA Polymerase in a reaction volume of $20 \mu \mathrm{l}$. Template DNA was initially denatured at $94^{\circ} \mathrm{C}$ for $5 \mathrm{~min}$ followed by 35 cycles of PCR 
amplification with the following parameters; 1 min denaturation at $94^{\circ} \mathrm{C}, 1 \mathrm{~min}$ annealing at $55^{\circ} \mathrm{C}$ and $1 \mathrm{~min}$ primer extension at $72^{\circ} \mathrm{C}$. A final extension was done at $72^{\circ} \mathrm{C}$ for $5 \mathrm{~min}$. The amplified products were resolved at $2.5 \%$ Agarose gel electrophoretically and visualized under UV.

Crossed seeds (F1) along with the two parents were planted during kharif 2017. For synchronization of flowering staggering of the recipient variety Keteki Joha was done in the research farm. Hybridity test was done and true F1s were marked. Back crossing was attempted between Keteki Joha x F1 followed by harvesting during December, 2017.

Harvested seeds of BC1F1, F2 along with the parents ISM and Keteki Joha were grown during Kharif 2018. For synchronization of flowering staggering of the recipient variety Keteki Joha was also carried out. Back crossing with the recurrent parent, Keteki Joha was attempted during kharif, 2018. Screening for pathogenicity carried out in $\mathrm{F} 2$ population.
Confirmation for presence of BB resistance genes with SSR markers carried out in the selected plants.

\section{Results and Discussion}

The PCR marker linked to $x a 13, X a 21$ did not detect any banding pattern of resistance as ISM in Keteki joha, conferring the absence of the resistance genes $x a 13$ and $\mathrm{Xa21}$ respectively in this variety (Fig. 1, lane 1-4). Amplification of genomic DNA of Keteki joha using marker linked to $\mathrm{Xa} 4$ and $x a 5$ showed the same banding pattern as ISM, may be due to the presence of $\mathrm{Xa4}$ and $x a 5$ genes in the rice variety Keteki Joha (Fig. 1, lane 5-8). Therefore, after the release of the variety, it showed tolerant reaction during later part of 90 s and first decade of $21^{\text {st }}$ century. However, the variety becoming susceptible during recent years may be due to the evolution of new pathotypes of BB. Therefore, it is essential to introgress xa13 and Xa21 to confer resistant against BB.

Table.1 BB resistance genes, their chromosome location, linked marker and primer pairs

\begin{tabular}{|c|c|c|c|c|}
\hline Gene & Chromosome & Linked marker & Primer pair & Reference \\
\hline \multirow[t]{2}{*}{$X a 4$} & \multirow[t]{2}{*}{4} & MP-STS & $\begin{array}{l}\text { MP1:ATCGATCGATCTTCACGAGG } \\
\text { MP2:TCGTATAAAAGGCATTCGGG }\end{array}$ & Ma et al., (1999) \\
\hline & & RM144 & $\begin{array}{l}\text { F: TGCCCTGGCGCAAATTTGATCC } \\
\text { R:GCTAGAGGAGATCAGATGGTAGTGCATG }\end{array}$ & Yoshimura et al.,(1992) \\
\hline \multirow[t]{2}{*}{$x a 5$} & \multirow[t]{2}{*}{5} & $\begin{array}{l}\text { RG556/DraI - } \\
\text { SNP }\end{array}$ & $\begin{array}{l}\text { F:TAGCTGCTGCCGTGCTGCGC, } \\
\text { R:AATATTTCAGTGTGCATCTC }\end{array}$ & $\begin{array}{l}\text { Huang et al., (1997), } \\
\text { Yoshimura et al.,(1995) }\end{array}$ \\
\hline & & RM122 - SSR & $\begin{array}{l}\text { F:GAGTCGATGTAATGTCATCAGTGC, } \\
\text { R:GAAGGAGGTATCGCTTTGTTGGAC }\end{array}$ & $\begin{array}{l}\text { Chen et al., (1997) } \\
\text { Ullah et al., (2012) }\end{array}$ \\
\hline \multirow[t]{2}{*}{ xa13 } & \multirow[t]{2}{*}{8} & $\begin{array}{l}\text { RG136 / HinfI - } \\
\text { SNP }\end{array}$ & $\begin{array}{l}\text { F:CCCAGAAAGCTACTACAGC, } \\
\text { R:GCAGACTCCAGTTTGACTTC }\end{array}$ & $\begin{array}{l}\text { Zhang et al., (1996), } \\
\text { Huang et al., (1997) }\end{array}$ \\
\hline & & xa13 & $\begin{array}{l}\text { F: GGCCATGGCTCAGTGTTTAT } \\
\text { R: CAGCTCCAGCTCTCCAAATG }\end{array}$ & \\
\hline \multirow[t]{2}{*}{$X a 21$} & \multirow[t]{2}{*}{11} & pTa248-STS & $\begin{array}{l}\text { F:AGACGCGGAAGGGTGGTTTCCCGGA, } \\
\text { R:AGACGCGGTAATCGAAAGATGAAA }\end{array}$ & $\begin{array}{l}\text { Ronald et al.,(1992), } \\
\text { Huang et al.,(1997) }\end{array}$ \\
\hline & & RM206 & $\begin{array}{l}\text { F: CCATGCGTTTAACTATTCT } \\
\text { R: CGTTCCATCGATCCGTATGG }\end{array}$ & Temnykh et al., (2001) \\
\hline
\end{tabular}


Fig.1 Identification of polymorphic markers for foreground selection

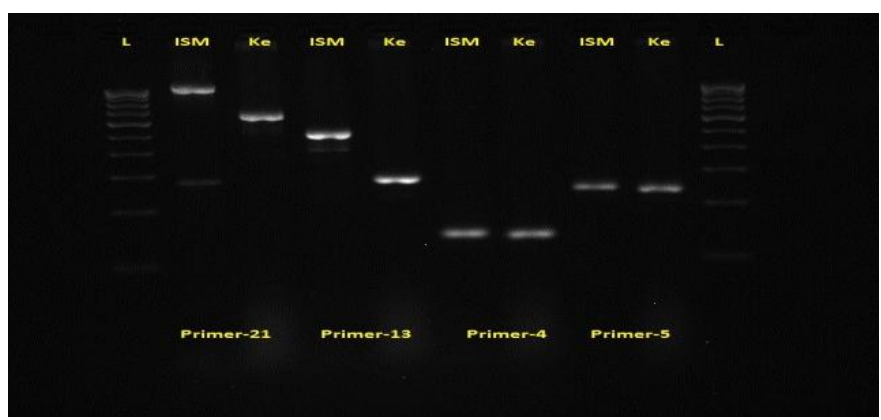

L:Ladder, ISM: Improved samba mahsuri, Ke:Keteki Joha

Fig.2 Hybridity test
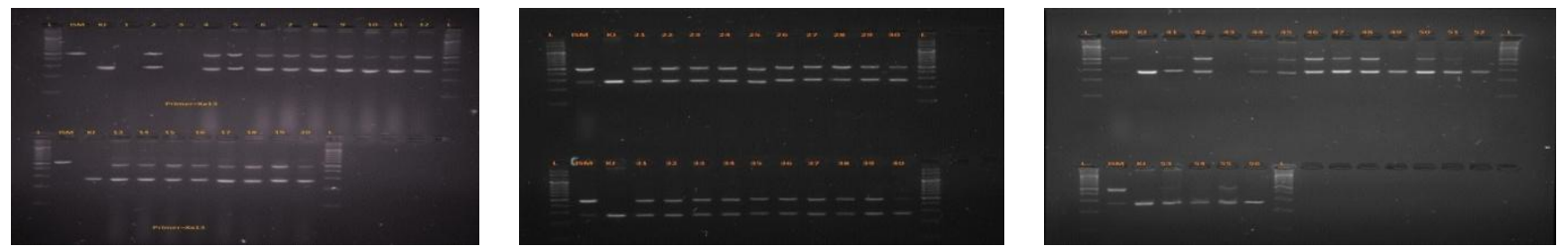

Fig.3\&4 Screening of F2 for xa13 and Screening of F2 for Xa21

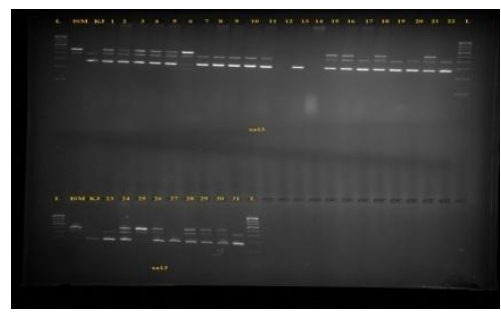

For $x a 13$ and $X a 21$, polymorphic markers xa13 promoter and pTa248-STS respectively were identified. For $\mathrm{Xa4}$ and $x a 5$ no polymorphism were recorded with the linked markers Npb181 and RM122 respectively (Fig. 1). This may be due to the presence of $\mathrm{Xa} 4$ and $x a 5$ in Keteki Joha.

We have attempted back cross 2. Further we have studied the genealogy of keteki joha and ISM and observed that both have some common ancestors. Moreover the grain quality of ISM is as per with the Keteki Joha. Therefore we have advanced the F1 to F2 generation and screened for $\mathrm{BB}$ resistant plant. The size of the F2 population was 3000 . From the F2 population we had selected 31

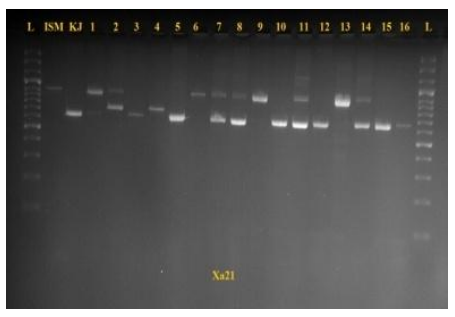

plants based on aroma and phenotypic acceptability. We identified 1 plant having all the three BB resistant genes i.e. $x a 5, x a 13$ and $X a 21$; 2 plants with $x a 13 ; 3$ plants with $X a 21$; 2 plants homozygous for Xa21 and heterozygous for xal3. We will advance the selected line by field RGA and expect to develop a high yielding, aromatic BB resistant variety within another two years.

\section{References}

Bhasin H, Bhatia D, Raghuvanshi S, Lore JS, Sahi GK and Kaur B. 2012. New PCRbased sequence-tagged site marker for bacterial blight resistance gene Xa38 of rice. Molecular Breeding, 30, 607-611. 
Cheema K, Grewal N, Vikal Y, Sharma R, Lore JS, Das A, Bhatia D, Mahajan R, Gupta V, Bharaj TS and Singh K. 2008. A novel bacterial blight resistance gene from Oryza nivara mapped to $38 \mathrm{~kb}$ region on chromosome $4 \mathrm{~L}$ and transferred to Oryza sativa L. Genet Res 90:397-407

Chetia, S. K.; Kalita, M.; Ali, M.S.; Das, B.C. and Ahmed, T. (2016). Variability of Xanthomonas oryzae pv. oryzae and introgression of BLB resistance in the popular rice varieties-Ranjit and Shraboni of Assam. Research on Crops. 17(2): 336-341.

Devadath S. 1989. Chemical control of bacterial blight of rice. In: Proceedings of the International Workshop on Bacterial Blight of Rice [International Rice Research Institute (ed.)], 14th-18th March 1988, IRRI, Manila, Philippines. p. 89-98.

Gu K, Yang B, Tian D, Wu L, Wang D, Sreekala C, Yang F, Chu Z, Wang GL, White FF and Yin Z. 2005. R gene expression induced by a type-III effector triggers disease resistance in rice. Nature 435:1122-1125

Hutin, M.; Sabot, F.; Ghesquire, A.;Koebnik, R. and Szurek, B. (2015). A knowledgebased molecular screen uncovers a broad - spectrum OsSWEET14 resistance allele to bacterial blight from wild rice. The Plant Journal. 84(4): 694-703.

Guillebeau, P. 1998. What to do about the food quality protection act? Or how can we protect the pesticides we need? Proc. S.E. Pecan Growers Association, 91: 65-69.

Khan, M.W.; Abbasi, F.M.; Masood, M.S.; Rabbani, A.; Abbasi, M.F.; Sajid, M.; Khan, U. and Ahmad, H.(2015). Identification of bacterial blight resistance gene $\mathrm{Xa} 7$ in rice (Oryzae sativa L.) through STS marker.
International Journal of Biosciences. Vol. 6, No. 2, p. 318-324.

Korinsak S, Sriprakhon S, Sirithanya P, Jairin J, Korinsak S and Vanavichit A. 2009. Identification of microsatellite markers (SSR) linked to a new bacterial blight resistance gene xa33 $(\mathrm{t})$ in rice cultivar 'Ba7'. Maejo International Journal of Science and Technology, 3, 235-247.

Lee KS, Rasabandith S, Angeles ER and Khush GS. 2003. Inheritance of resistance to bacterial blight in 21 cultivars of rice. Phytopathology, 93, 147-152.

Mamgain A, Roychowdhury $\mathrm{R}$ and Tah $\mathrm{J}$. 2013.Alternaria pathogenicity and its strategic controls. Research Journal of Biology, 1: $1-9$.

Mishra D, Vishnupriya MR, Anil MG, Konda K, Raj Y, et al., (2013) Pathotype and Genetic Diversity amongst Indian Isolates of Xanthomonas oryzae pv. oryzae. PLoS ONE 8(11): e81996. doi: 10.1371/journal.

Natrajkumar P, Sujatha K, Laha GS, Srinivasarao, K, Mishra B and Viraktamath BC. 2012. Identification and fine-mapping of Xa33, a novel gene for resistance to Xanthomonas oryzae pv. oryzae. Phytopathology, 102, 222228.

Nino-Liu DO, Ronald PC, Bogdanove A.J. 2006. Xanthomonas oryzae pathovars: model pathogens of a model crop. Molecular Plant Pathology, 7: 303-324. DOI: 10.1111/J.1364-3703.2006.00344.

Sanchez AC, Brar DS, Haung N, LiZ and Khush GS. 2000. Sequence tagged site marker assisted selection for three bacterial blight resistance genes in rice. Crop Science, 40: 792-797. DOI:10.2135/cropsci2000.403792

Sattari A., Fakheri B., Noorozi M., Gudarzi Moazami Kh., International Journal of Allied Sciences (c) 2014 IJFAS Journal2014-3-8/895-902/ 31 August, 2014, 
IJFAS.

Singh S, Sidhu JS, Huang N, Vikal Y, Li Z, Brar DS, Dhaliwal HS, Khush GS. 2001. Pyramiding three bacterial blight resistance genes (xa5, xa13 and $\mathrm{Xa21}$ ) using marker-assisted selection into indica rice cultivar PR106. Theoretical and Applied Genetics, 102:1011-1015 DOI: $10.1007 / \mathrm{s} 001220000495$.

Sun X, Cao Y, Yang Z, Xu C, Li X and Wang S.2004. Xa26, a gene conferring resistance to Xanthomonas oryzae $p v$ oryzae in rice, encodes an LRR receptor kinase-like protein. The Plant Journal, 37, 517-527.
Sundaram RM, Vishnupriya MR, Biradar SK, Laha GS and Reddy GA. 2008. Markerassisted Introgression of bacterial blight resistance in Samba Mahsuri, an elite indica rice variety. Euphytica, 160:411422. DOI: 10.1007/s10681-007- 9564-6.

Yang D, Sanchez A, Khush GS, Zhu Y and Huang N. 1998.Construction of a BAC contig containing the xa5 locus in rice. Theor Appl Genet 97:1120-1124.

Zhang Q. 2005. Utilization and strategy of gene for resistance to rice bacterial blight in China. Chinese Journal of Rice Science, 19(5): 453-459.

\section{How to cite this article:}

Gongotri Hazarika, Sanjay Kumar Chetia, Sunayana Bordoloi, Amrit Tamuly and Ahmed, T. 2019. Studies on BB Resistance Introgression in Aromatic Rice Variety Keteki Joha. Int.J.Curr.Microbiol.App.Sci. 8(09): 81-87. doi: https://doi.org/10.20546/ijcmas.2019.809.012 